\title{
Brexit and Western Balkans
}

\author{
Jovan Teokarevic, PhD 1
}

Received: 08.07.2021

Available online: 20.12 .2021

\section{Abstract}

This article analyses effects of Brexit on relations between the United Kingdom and the Western Balkan countries (Albania, Bosnia and Herzegovina, Kosovo, Montenegro, North Macedonia, and Serbia). First, the symbolism of the UK departure from the EU for the Western Balkans is explained. In the following step, multiple types of relations (in trade, security, culture) between the post-Brexit UK and this region are analysed using the theoretical concepts of linkage, leverage and soft power. Finally, the consequences of Brexit on further EU enlargement are presented. The research has confirmed the initial hypotheses. First, as expected, the volume and density of UK-Western Balkan relations will be reduced after Brexit. Second, Western Balkans is of a very limited interest for the UK, primarily in security. Third, Brexit has not in a serious way changed the already existing low chances of EU accession for the Western Balkan countries. The reason for this has little to do with the UK's presence in or absence from the EU and is rather a consequence of the majority view within the Union (that Britain had already shared before Brexit) concerning further enlargement and low level of preparation of Western Balkan countries for EU membership.

Keywords: Brexit, United Kingdom, Western Balkans

JEL: F53, F35, F14

\section{Introduction}

The United Kingdom's (UK) exit from the European Union (EU) has been an interesting and important topic for a vast amount of theoretical and policy analysis done in the aftermath of the so-called Brexit referendum of 2016. Most analytical efforts have dealt with the consequences of Brexit on the UK and the EU and their mutual relations. Some attention has been also paid to the effects of this event on UK relations with other countries and regions in the world. The Western Balkan region (consisting of

1 Associate professor of Comparative Politics, Faculty of Political Science, University of Belgrade, Serbia; Visiting Professor, College of Europe, Natolin Campus, Poland. E-mail: jovan.teokarevic@fpn.bg.ac.rs 
Albania, Bosnia and Herzegovina, Kosovo, North Macedonia, Montenegro and Serbia) has remained under-researched in this sense. This article will try to rectify this situation through the review and explanation of the post-Brexit UK's relations with this region.

The main research question is: have relations between the UK and the Western Balkans changed after Brexit, and if yes - how?

This article has four parts. First a theoretical framework for analysis will be outlined. Then, the symbolism of the UK departure from the EU for the Western Balkans will be explained. In the following step, multiple types of relations between the post-Brexit UK and this region will be dealt with. Finally, the consequences of Brexit on further EU enlargement will be presented.

\section{Theory and methodology}

The theoretical-methodological framework of this research rests on two complementary contributions of contemporary political science literature: the concepts of linkage and leverage, on the one side, and the concept of soft power, on the other.

Way and Levitsky conceptualize the post-Cold War international environment as operating along two dimensions: Western leverage, or governments' vulnerability to external pressure, and linkage to the West, or a density of a country's economic, political, organisational, social and communication ties to the West (Way and Levitsky, 2007: 50). Although these authors were trying to identify something else - Western influence upon the democratisation of other countries, their theory could be with some modifications used in our case, which is why the word "West" can be replaced with the "UK".

While researching the influence of non-Western actors in the Western Balkans, Bieber and Tzifakis based their methodology on the Levitsky-Way theory. They, however, adjusted it to some extent, reducing six dimensions of linkage to only three: military/ political, economic and societal. In addition, Bieber and Tzifakis argue that "linkages may either function as mediums for the transmission of influence or as sources of influence in their own right" (Bieber and Tzifakis, 2020: 6).

As for the second methodological tier of this article - the well-known soft power concept - I will refer to Joseph Nye, of course. He explained the difference between the hard and the soft power in the following way: "Power is the ability to affect others to get the outcomes one prefers, and that can be accomplished by coercion, payment, or attraction and persuasion. Soft power is the ability to obtain preferred outcomes by attraction rather than coercion or payment" (Nye, 2017: 1). I am using the concepts of leverage and soft power as if they have the same meaning. In addition, as will be shown later in the text, I will also present two practical implementations of the soft power concept on the case of the UK. 


\section{Symbolism of the UK departure from the EU}

Before I move on to the more fact-based accounts concerning the implications of Brexit on the UK-Western Balkan relations, it is necessary to say something about the equally important symbolism of Brexit for the region in question.

First of all, this unprecedented move seriously shook the prevailing assumption of Western Balkan governments and societies about the EU's "magnetism" for all or most European countries. It was very difficult for local actors in the region (and not only for them, of course) to understand why one of the key EU member states decided to leave the Union after more than forty years of membership. All decades-long mantras on the $\mathrm{EU}$ as the most natural and convenient place for European states and societies began to be seriously questioned.

The image of the EU as a powerful fortress capable of offering safe heaven particularly for weak latecomers began to fade away, too, fuelling in addition the rising wave of Euroscepticism within the Western Balkans. Anti-European forces in the region welcomed Brexit as an important additional argument that the EU project was not sustainable.

For many observers, Brexit was seen as the unfortunate repetition of the disintegration of Yugoslavia in the early 1990s, at the moment when Europe intensified its integration after the Cold War. The causes of the two divorces seemed similar: selfish and xenophobe nationalism triumphed in both cases (Srbija i Bregzit, 2016: 1).

Brexit has echoed everywhere, including in the region we investigate, with the accompanying disintegration tendencies in the UK (the 2014 Scotland's independence referendum and the divide within the UK on Brexit referendum). In a very serious way this dashed hopes in the Western Balkans that EU membership could possibly reinforce the integrity and the stability of the states in the region - something they very much expected from their future EU membership.

The UK officials kept repeating that while their country is leaving the EU, it is not leaving Europe and thus it can still support states that are willing to join. This is certainly possible, since both the EU and the UK share most of the same set of political and economic values. At the same time, it has been difficult or rather impossible to sell to the Western Balkans such a paradox that the state which is leaving a club is pushing the others to join.

Two other previous symbolic disappointments only reaffirmed the region's disbelief in the EU. The first one was the complete bankruptcy of Greece at the beginning of the last decade. To everyone's dismay in the region, Greece as the first Balkan country to enter the EU failed to become the first genuinely European country in the Balkans. Equally important was the symbolism of Croatia's economic and democratic underperformance in the wake of its accession in 2013. 


\section{UK linkage and leverage}

\section{Trade}

The review of the UK linkage with the Western Balkans should begin with the traditionally most important factor - the volume of bilateral trade. As can be seen from Table 1, UK trade with the Western Balkans is negligible. Total imports from the region in 2017 amounted to only 316 million pounds, while the value of total exports was a little more than 1 billion pounds. No significant changes have been recorded since 2017.

Table 1: UK trade with the Western Balkans

\begin{tabular}{|l|c|c|}
\hline \multicolumn{1}{c|}{ Country } & Imports & Exports \\
\hline Albania & $£ 4 \mathrm{~m}$ & $£ 24 \mathrm{~m}$ \\
\hline Bosnia and Herzegovina & $£ 57 \mathrm{~m}$ & $£ 57 \mathrm{~m}$ \\
\hline Kosovo & $£ 0 \mathrm{~m}$ & $£ 3 \mathrm{~m}$ \\
\hline Macedonia & $£ 51 \mathrm{~m}$ & $£ 770 \mathrm{~m}$ \\
\hline Montenegro & $£ 0 \mathrm{~m}$ & $£ 22 \mathrm{~m}$ \\
\hline Serbia & $£ 204 \mathrm{~m}$ & $£ 169 \mathrm{~m}$ \\
\hline Total & $£ 316 \mathrm{~m}$ & $£ 1.045 \mathrm{bn}$ \\
\hline
\end{tabular}

Source: Office for National Statistics (2017)

Within the import category, Serbia stands out, while within the export category this is North Macedonia. Trade with North Macedonia, the UK's largest trading partner in the Western Balkans, has increased lately and in 2019 it was worth $£ 1.8$ billion (Croner-i, 2021).

In 2020, Serbia's foreign trade with UK was worth €529.3 million, marking a $5 \%$ decrease compared to the previous year (with a $10 \%$ surplus on Serbia's side). Nevertheless, the UK is only in the 21 place within Serbia's export destinations, and export to UK represents a mere 1.7\% of total Serbia's export (Privredna komora Srbije, 2021).

UK expert on the Western Balkans James Ker-Lindsay explained the low level of trade in the following way: "British companies have been much more focused on wealthier European markets, or have wanted to pursue trade with Commonwealth countries, where there are often established links. Few want to explore opportunities in the Balkans, especially as the entire population of the six counties is less than 20 million people" (House of Lords, 2018: 41).

Yet chances for bigger trade in future have been growing, as the UK recently signed Partnership, Trade, and Cooperation Agreements with Western Balkan countries. This was already done with North Macedonia, Albania and Serbia, and negotiations are 
underway with other countries. In these agreements the UK committed itself to equally favourable conditions for Western Balkan countries as those laid down in Stabilisation and Association Agreements with the EU. This means that most export products from the Western Balkans will be imported in the UK without the import tariffs, which will make them cheaper and more attractive (Privredna komora Srbije, 2021).

\section{"UK enduring commitment to the region"}

Over the last years various UK governments have reiterated on many occasions their "enduring commitment" to the Western Balkan region, regardless of Brexit. The peak of this commitment was reached in 2018, when the UK hosted a conference within the "Berlin Process". This format has since 2014 brought together several EU member states and all countries of the region, with the aim of invigorating the stalled process of EU enlargement, primarily through investments in infrastructure and energy.

As a host of the 2018 "Berlin Process" conference, the UK Government presented a very ambitious plan for the Western Balkans. It included the new package of funding and engagement with the region (Gov.UK, 2018), with these most important pledges:

- increasing UK funding to the region by over 95\% from f41 million in 2018/19 to f80 million in 20/21 from the Conflict, Security and Stability Fund;

- doubling the number of UK staff working in the region on the security issues;

- launching the Balkans Organised Crime Observatory, jointly with the Austrian and Norwegian governments;

- improving the region's cyber capability through a f1 million investment in training and advisory activities;

- agreeing a Joint Declaration on the Principles of Information-Exchange in the Field of Law Enforcement;

- chairing a senior-level Security Commitments Steering Group;

- extending the Pan Balkans Strategic Reserve Force (SRF) for another year, which is held at readiness in the UK to move into the Western Balkans if the security situation deteriorates or the UK needs to support stability in the region;

- committing $f 10$ million to help build digital skills and employment prospects for young people in the Western Balkans;

- providing an additional $f 1$ million to help the region address difficult legacy issues.

This ambitious package presents in a very clear way the UK's priorities in the Western Balkans. They revolve around three main topics: security, good governance (with a special emphasis on fight against organised crime and corruption), and economic reforms. The UK has been active on these issues during its membership in the EU, as well, which exposes an important continuity, raising hopes that the UK engagement will continue along the same lines. 
When it comes to the promised radical increase in UK's financial aid to the region, it was in fact reduced in the meantime, due to the worsening of economic situation in the UK and the Covid 19 pandemic. In late 2020 the UK Government announced a temporary reduction in the UK's aid budget from $0.7 \%$ to $0.5 \%$ of national income. "We will return to $0.7 \%$ when the fiscal situation allows", the Chancellor of the Exchequer promised (Gov.UK, 2020). As the portal Open Democracy found out from the leaked UK Government documents in Spring of 2021, the proposed cut for the Western Balkans will be $50 \%$ (see Table 2), which will certainly affect most of the priorities from the mentioned package (Open Democracy, 2021).

Table 2: Reduced UK Aid Budget

\section{Proposed cuts to Overseas Development Aid budget}

Sahel

Syria

Libya

Somalia

Democratic Republic of Congo

South Sudan

Nigeria

West Balkans

\section{$93 \%$}

\section{$67 \%$}

$63 \%$

$60 \%$

$60 \%$

$59 \%$

$58 \%$

$50 \%$

UK Government proposed cuts to Overseas Development Aid budget for year 2020/21 - 21/22 broken down by country.

Source: Leaked UK Government documents

openDemocracy 8

\section{Security}

For the UK, the Western Balkans remains primarily a security challenge due to the region's still high conflict potential, but also because of migratory trends and rising geopolitical competition with non-Western rivals (Russia, China and Turkey). All this could potentially pose a threat to European and UK security.

The UK has been one of the main security actors in the region, particularly during the military conflicts in the 1990s and ever since. Western Balkans has profited from 
a rich and diversified contribution and experience of the UK in providing security and stability in the region, particularly in war-torn states of Bosnia and Herzegovina and Kosovo. It has been the leading Western partner in NATO and EU missions throughout the Western Balkans. The UK's participation in the so-called Quint Group (together with the US, France, Germany and Italy) is of special significance in this context, because of the Group's unmatched role in constant monitoring of the situation in the region. In addition to being a leading member of NATO, capable of projecting force way beyond its borders, the UK has remained very influential as permanent member of the UN Security Council, and also through OSCE and other international organisations.

Although important, the Western Balkans is, however, not the area of prime security interest for the UK, and it was accordingly mentioned only once in UK Government's recent (March 2021) Integrated Review of Security, Defence, Development and Foreign Policy (Global Britain..., 2021: 72). There, the UK commitment to collective security in various regions of the world includes the Western Balkans. Yet with the increasing security stabilisation in the region, the UK presence has transformed into an equally important softer security provider, embedded until recently within the EU presence in the region (Economides in Markovich, 2018: 473).

Security cooperation between the two sides has taken many different forms, including with countries that are not NATO members, like Serbia. Disagreement between the UK and Serbia on the status of Kosovo (James Ker-Lindsay in Markovich, 2018: 477-486) (the former one is a strong supporter of Kosovo's independence in 2008, the latter one has not recognised its former province's independence) in effect led to temporary crisis in bilateral relations that was largely overcome in the meantime, and replaced by intense multi-faceted security cooperation both on the bilateral level and through NATO's Partnership For Peace Program of which Serbia is member. Russia's growing influence in Serbia and the strong bi-lateral relations might become another contentious issue, considering that the UK is determined to counter this trend in the Western Balkans.

\section{Western Balkan communities in the UK}

High presence of politically active communities from the Western Balkans in the UK would certainly increase their voice and influence on the UK policy towards the region. That is, unfortunately, not the case, as Table 3 clearly shows.

In 2017 there were 55,000 people estimated to be residing in the UK whose country of birth was in the Western Balkans, with the majority $(36,000$, equivalent to $65 \%)$ of Albanian origin. Nationals from the Western Balkans represent only $0.084 \%$ of the UK population (Impact of visa..., 2019). To put these figures in context, one should just compare them with the number of people originating from two other Balkan states Bulgaria and Romania $(413,000$ in total in 2017 - a nearly $80 \%$ rise since 2014 ) (The Guardian, 2017), or from Poland $(815,000$ in 2020, down from over a million in 2017) (Statista, 2020). 
Table 3: Western Balkan communities in the UK
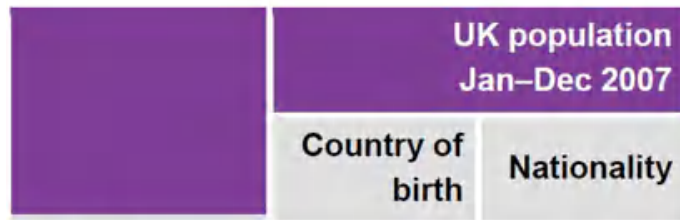

UK population

Jan-Dec 2007

Jan-Dec 2017

\begin{tabular}{l|r|r|r|r|}
\hline FYROM & 3,000 & 2,000 & 2,000 & 1,000 \\
\hline Montenegro & $\mathrm{n} / \mathrm{a}$ & $\mathrm{n} / \mathrm{a}$ & $\mathbf{1 , 0 0 0}$ & $\mathrm{c}$ \\
\hline Serbia & 3,000 & 1,000 & 12,000 & 7,000 \\
\hline Albania & 12,000 & 11,000 & 36,000 & 26,000 \\
\hline $\begin{array}{l}\text { Bosnia and } \\
\text { Herzegovina }\end{array}$ & 9,000 & 4,000 & 4,000 & 1,000 \\
\hline TOTAL & $\mathbf{2 7 , 0 0 0}$ & $\mathbf{1 8 , 0 0 0}$ & $\mathbf{5 5 , 0 0 0}$ & $\mathbf{3 5 , 0 0 0}$ \\
\hline
\end{tabular}

Source: Impact of visa liberalisation... (2019).

The number of $U K$ visitor visa grants to visitors from the Western Balkans went up from 12,934 (2007) to 23,878 (2017) over the decade - an increase of $85 \%$. The interest of Western Balkan nationals in the UK has remained high, despite the strict and expensive visa regime in place. In contrast to the countries of the Schengen Area that allow citizens of the Western Balkan countries (except for those from Kosovo) a visa free entry for 90 days, the UK has never lifted the visa regime for them. Trying to get to the UK is thus neither easy nor cheap: a short-term visa (valid for up to 6 months for single or multiple entries) costs EUR 115, while the price of the longer term visa (valid up to 2 years) is EUR 437 (Visa application fees, 2021).

\section{UK soft power and leverage}

The UK has for a long time in recent years been the country with the highest soft power in the world (The Economist, 2015). According to the joint research project Soft Power 30 of Portland Communications, Facebook and Center for Public Diplomacy, the UK was overtaken in 2016 by the US (Soft power, 2016). As the polls were finished earlier in that year, neither the Brexit vote of June 2016 nor the Donald Trump victory at the US presidential elections in November of the same year had anything to do with the UK's underperformance. The latter was rather the consequence of the rising US soft power in the preceding years, under the Barack Obama administration.

Yet Brexit and Trump did affect the performance of the two leading countries in the years to come. By 2019, according to the same source, France climbed to the first place of the countries with the biggest soft power, and Britain came in second, while the US ended as the fifth out of 30 most influential countries. 
Another similar research on soft power has been carried out by the Brand Finance, which unlike the Portland's work, continued the research after 2019. In their Global Soft Power Index 2021 they recognise the reduction of the UK's soft power (Global Soft Power Index, 2021). The country dropped to the third place, while Germany became the world's No. 1 "soft power superpower", followed by Japan. The US in the meantime, heavily influenced by Trump's presidency, became the worst performing nation in the ranking, dropping down to the $6^{\text {th }}$ position.

No matter how impossible it may be to fully compare the results of two different (albeit similar) pieces of research, it is clear that the UK's reputation in the world has been only partially affected by Brexit. Falling down to the second or third position during a period of half a decade after Brexit vote, after many years of undisputed domination in the soft power ratings, proves that the UK's soft power is still among the highest in the world, and is likely to remain such in many years to come. This runs almost completely counter to many of the expectations voiced by Brexit critics that disappointment with the UK's exit from the EU should be followed by a much more persuasive drop in its soft power (MacDonald, 2016). It seems, however, that the pillars of the UK traditional soft power have remained quite strong despite a high level of unpopularity of Brexit both inside the island and beyond.

This is not to say, however, that the UK's soft power survived Brexit unscathed. German Die Zeit described one important aspect of it in the following way: "Brexit undoubtedly diminishes this soft power too. Indeed, one of the things that has been so upsetting for young people in Britain (overwhelmingly anti-Brexit) is the resentful, disrespectful, xenophobic and inward-looking image of their country that its political leaders have projected since 2016. It is not the way they see themselves, but they know that this image will hang around for a long time like a bad smell" (Zeit online, 2021).

Culture has remained the main source of UK's influence and appreciation across the globe and the English language is its most important instrument. In its study on the impact of English, the British Council - another extremely influential soft power instrument on a global scale - said the following: "The English language is perhaps the United Kingdom's greatest and yet least-recognised international asset. It is a cornerstone of our identity and it keeps us in the mind of hundreds of millions of people around the world, even when they are not talking to us" (Ef.com, 2018). As an indispensable tool in both professional and private lives, and in communication, the same source says this about this global language: "English is now spoken by a quarter of the world's population, enabling a true single market in knowledge and ideas. Nonnative speakers now substantially outnumber native speakers and as a result, English increasingly belongs to the world rather than to any one country" (Ibid.).

Like so many other states, all Western Balkan countries have in the past years continued or introduced for the first time courses of English in elementary and secondary schools, often as mandatory. That certainly contributed to the higher level of 
proficiency in English across the region. The situation is in this sense most favourable in former Yugoslav republics with a longer tradition of teaching this language at schools: according to the 2020 EF English Proficiency Index, Croatia thus ranks $13^{\text {th }}$ and Serbia $15^{\text {th }}$ in the world, which is not bad at all (English Proficiency Index, 2020).

Another important pillar of the UK's soft power is the country's super rich classic and modern cultural heritage - highly popular in the Western Balkans as elsewhere. UK universities of outstanding quality have been a constant target for students from the whole world and from the Western Balkan region, as well. Indicatively, the 2021 Times Higher Education World Rankings found that two of the world's top ten universities, including the world's top university - the University of Oxford - are in the UK. Seven of the top 50 and 26 of the top 200 universities are also in the UK (Times Higher Education, 2021).

At least two additional tools have contributed to the UK's soft power globally and in the region under scrutiny in this article. The first one is $B B C$ - the most influential media outlet in the world that broadcasts in more than 40 languages and reaches 426 million viewers and listeners abroad per week. Its reputation is based on its unique mix of high professionalism and independence from Government. In one Western Balkan country - Serbia - the BBC program in the vernacular was first closed down in 2011, to be reopened seven years later, which certainly increased its influence, along with the UK soft power (N1, 2017). This time around, the comeback of the BBC program in Serbian was not only about accurate and balanced reporting within this country's endangered media freedoms. It was also an effort to counter Russian propaganda another important UK priority (Politico, 2018).

Last but not least, the UK's parliamentary system with its high governance standards and respect for the rule of law and for human rights has increased the country's relevance and influence. Even after Brexit the UK will remain an important country for the democratic conditionality policy vs. the Western Balkan states in these areas, not least through its Westminster Foundation for Democracy. Hence many observers are suggesting that post-Brexit "Global Britain" should, among other foreign policy objectives, "organise a coherent strategic response to the global erosion of liberal democracy and the buckling of the rule-based world order in the face of revisionist powers and systemic decline", "cultivate democratic solidarity and with like-minded consolidated democracies within international institutions, and through 'missioncoalitions' and other ad hoc partnerships", and "support international mechanisms that defend and promote democratic and human rights values, rooted in the principles of informed popular consent and universal capabilities" (The Foreign Policy Centre, 2020: 6). These goals are particularly relevant for the Western Balkans that is currently undergoing a dramatic backsliding in the areas of democracy and the rule of law. 


\section{Brexit and EU enlargement}

The UK was for a long time a staunch supporter of EU enlargement, primarily as a way to prevent the Union's further "deepening" or possible federalisation. This changed even before Brexit, when immigration became the issue of greatest concern in the UK (Ker-Lindsay, 2015, 2017). The UK thus ceased to be a "natural partner" of Western Balkan EU hopefuls, and joined the dominant non-enlargement tide within the EU.

During EU-UK negotiations the issue of enlargement was naturally missing. Even earlier, the newly elected Juncker's European Commission declared in 2014 that there would be no enlargement during its term until 2019. That was one of the main signs of the EU's disengagement in the Western Balkans that had begun several years earlier. After almost a decade of marginalisation of the region, an important policy turn occurred in early 2018, when the EU announced an ambitious re-engagement with the Western Balkans, declaring for the first time that the Western Balkan accession is in EU's own political, security and economic interests (Committee..., 2018).

Yet high hopes in the region were shortly dashed with the French "no" to further enlargement before the EU sorts out its own problems. The French non-paper from the end of 2019 (Politico, 2019) prompted the adoption of the new enlargement methodology by the European Commission in February of 2020 (Committee..., 2020). The expected acceleration of enlargement unfortunately did not materialise. Out of six countries of the region, Montenegro and Serbia continue their accession talks at a very slow pace, while North Macedonia and Albania are still not allowed to begin accession negotiations, although they were given the green light by the EU back in March 2020. The two remaining states - Bosnia and Herzegovina and Kosovo - are still in the category of potential candidates for EU membership with even smaller chances for accession than the other four.

All this resulted in the slowing down of all reforms in the Western Balkan candidate and potential candidate countries, with the worst results in the key areas of rule of law and democracy where substantial backsliding can be detected in comparison with previous years. Another result is the rising Euroscepticism in the region. As can be seen from Chart 1, EU membership is still popular in the Western Balkans, including in the increasingly Eurosceptic Serbia. Pessimism, however, prevails regarding fast accession: "my country will never be in the EU" was the expectation given in this poll from late 2020 by $32.7 \%$ of Serbia's citizens, $28.1 \%$ of the Bosnia's ones, $25.7 \%$ of those from Macedonia and $20.9 \%$ of Albania's citizens. Equally worrying are high figures for other options - expected accession in the next 5, 10 and 20 year. This speaks volumes about the realistic attitudes among rank and file citizens, who understand that their countries are not ready for EU membership, nor are they welcome to join the Union. 


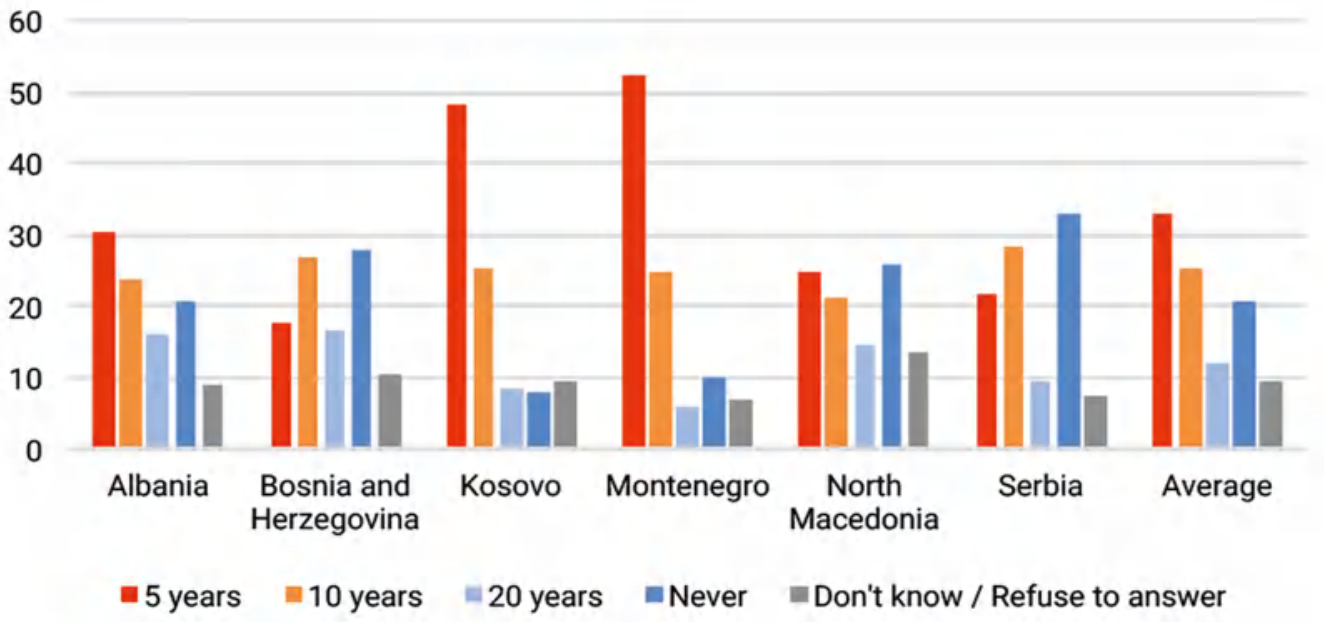

Chart 1. Expectations about one's country accession to EU over next 5/10/20 years or never Source: BiEPAG, 2020: 5

The long lasting enlargement fatigue within the EU was finally reduced only in 2019, by a slim majority (44\% vs. $42 \%$ ) of respondents in EU member states, who said they would support further enlargement. But, as Chart 2 shows, EU enlargement policy is the least popular of all major EU policies (Pushing on a String, 2020).

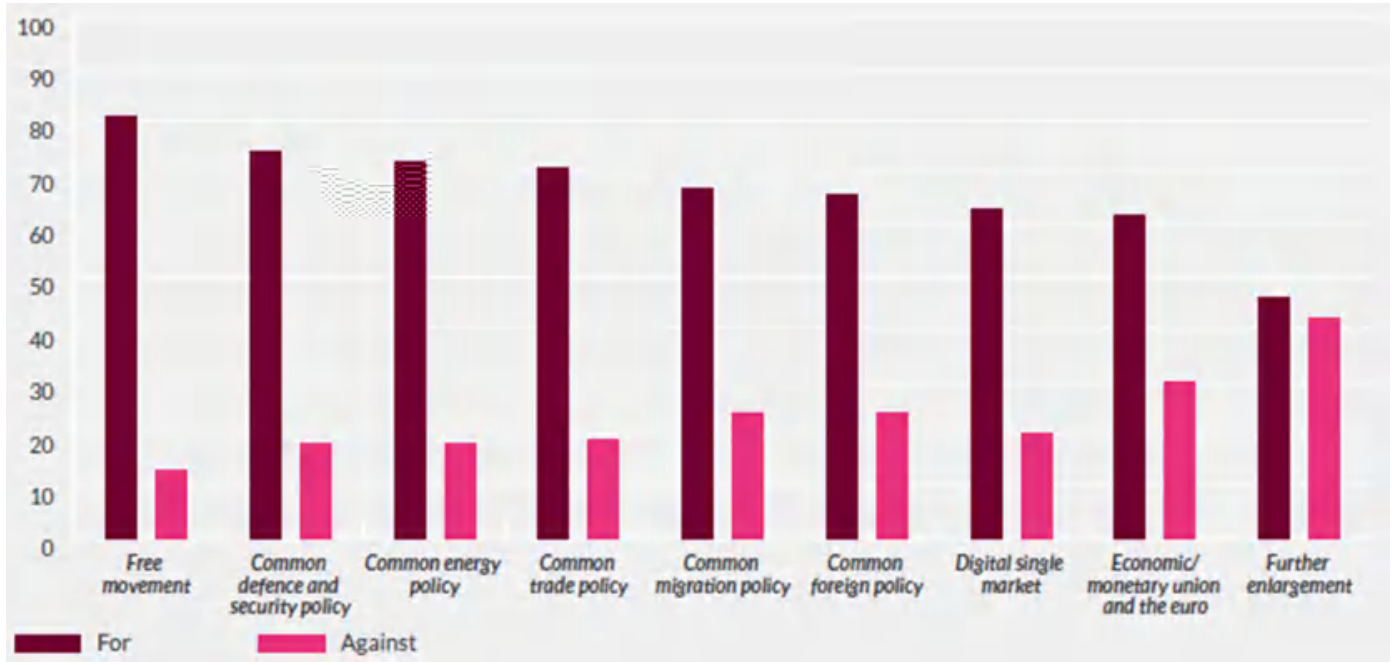

Chart 2. Views of EU citizens on common policy areas (in percent)

Source: Eurobarometer, 2019

The end result is that chances for EU accession of Western Balkan countries anytime soon are very slim, because these countries are obviously not ready for membership and at the same time further enlargement in the region is not popular in the EU. That 
is why one can conclude with great certainty that this result would not have been different even if the UK were still member of the EU.

As for the prospects of the UK's possible influence on the Western Balkan countries' EU membership, there is no doubt that it will be reduced. Outside the EU, the UK will have far less direct leverage on necessary reforms in the countries of the region, even though the political, economic and social values promoted by the UK and in the region are compatible with the EU conditionality policy. Countries of the region will at the same time lose considerable interest in stronger relations with the UK and will try to rely on other powerful EU member states that could possibly help them on their way to membership.

\section{Conclusions}

The initial hypotheses have been confirmed:

First, as expected, the volume and density of UK-Western Balkan relations will be reduced after Brexit. Second, Western Balkans is of a very limited interest for the UK, primarily in security. Third, Brexit has not changed in a serious way the already existing low chances of the Western Balkan countries for EU accession. The reason for this has little to do with the UK's presence in or absence from the EU and is rather a consequence of the majority view held within the Union (that Britain shared already before Brexit) concerning further enlargement and the low level of preparedness of Western Balkan countries for EU membership.

\section{References}

Balkans in Europe Policy Advisory Group (BiEPAG). (2020). Between a Rock and a hard Place: Public Opinion and European Integration in the Western Balkans, p. 5. Available at: https://biepag.eu/wp-content/uploads/2020/12/Between-a-rockand-a-hard-place-English-1.pdf (last visited May, 2021).

Bieber, F. and Tzifakis, N.(2020). The Western Balkans in the World. Linkages and Relations with Non-Western Countries. London and New York: Routledge.

Committee and the Committee of the Regions (2018). A credible enlargement perspective for and enhanced EU engagement with the Western Balkans. (n.d.). [online] . Available at: https://ec.europa.eu/info/sites/info/files/communicationcredible-enlargement-perspective-western-balkans_en.pdf (last visited June 27, 2021).

Committee and the Committee of the Regions (2020) Enhancing the accession process -A credible EU perspective for the Western Balkans. (n.d.). [online] . Available at: $\quad$ https://ec.europa.eu/neighbourhood-enlargement/sites/near/files/ enlargement-methodology_en.pdf (last visited June 20, 2021). 
Croner-i. (2021) UK adds North Macedonia to list of post-Brexit trade partners [online] Available at: https://app.croneri.co.uk/whats-new/uk-adds-north-macedonialist-post-brexit-trade-partners (last visited June 22, 2021).

Ef.com. (2018). EF EPI 2018 - EF English Proficiency Index. [online] Available at: https:// www.ef.com/wwen/epi/ (last visited June 22, 2021).

English Proficiency Index, 2020

Global Britain in a competitive age (2021). The Integrated Review of Security, Defence, Development and Foreign Policy CP 403. (n.d.). [online] . Available at: https:// assets.publishing.service.gov.uk/government/uploads/system/uploads/ attachment_data/file/975077/Global_Britain_in_a_Competitive_Age-_the_ Integrated_Review_of_Security_Defence_Development_and_Foreign_Policy. pdf. (last visited July 13, 2021).

Global Soft Power Index 2021: "UK Ranked 3rd in World for Soft Power Prowess" | Press Release | Brand Finance. [online] Available at: https://brandfinance.com/ press-releases/uk-ranked-3rd-in-world-for-soft-power-prowess (last visited July $7,2021)$.

GOV.UK (2020). "Changes in the UK's Aid Budget in the Spending Review.". Available at: https://www.gov.uk/government (last visited June 20, 2021).

GOV.UK. (2018). "PM reveals package of measures to promote a more peaceful, prosperous and democratic Western Balkans". [online] Available at: http:// www.gov.uk/government/news/pm-reveals-package-of-measures-to-promotea-more-peaceful-prosperous-and-democratic-western-balkans (last visited July 7, 2021).

House of Lords (2018). "Select Committee on International Relations 1st Report of Session 2017-19 The UK and the future of the Western Balkans". (n.d.). [online]. Available at: https://publications.parliament.uk/pa/ld201719/ldselect/ Idintrel/53/53.pdf (last visited July 7, 2021).

Impact of visa liberalisation on countries of destination. (2019). "National contribution from the United Kingdom Home Office Analysis and Insight". [online]. Available at: https://ec.europa.eu/home-affairs/sites/default/files/27a_unitedkingdom_ visa_liberalisation_en.pdf (last visited July 7, 2021).

Izvoz u Veliku Britaniju. (2020). "Novi tarifni režim od 1. januara 2021". [online] Available at: https://plutonlogistics.com/izvoznici/izvoz-u-veliku-britaniju-novitarifni-rezim-od-1-januara-2021/ (last visited July 7, 2021).

Ker-Lindsay, J. (2015). "Britain, "Brexit" and the Balkans". In The RUSI Journal, 160(5), pp. 24-29.

Ker-Lindsay, J. (2017). "The United Kingdom and EU Enlargement in the Western Balkans: From Ardent Champion of Expansion to Post-Brexit Irrelevance". In: Southeast European and Black Sea Studies, 17 (4). pp. 555-569.

MacDonald, S. (2016). "The impact of Brexit on the UK's reputation, influence and soft power". In: Cultural Trends, 25(4), pp. 280-286. 
Markovich, S.G. (2018). British-Serbian Relations from the 18th to the 21st Centuries. Belgrade: Faculty of Political Science, University of Belgrade.

N1. (2017). "BBC uskoro opet na srpskom". [online] Available at: https://rs.n1info.com/ vesti/a233079-bbc-uskoro-opet-na-srpskom/ (last visited July 7, 2021).

Nye, J. (2017). Soft power: the origins and political progress of a concept. Palgrave Communications, 3, p.17008.

Office for National Statistics. (2017). Who does the UK Trade with?, 21 February 2017. Available at: https://visual.ons.gov.uk/uk-trade-partners/ (last visited July 7, 2021).

Open Democracy. (2021). "UK government accused of "grotesque betrayal" as full foreign aid cuts revealed". [online] Available at: https://www.opendemocracy. net/en/opendemocracyuk/uk-government-accused-of-grotesque-betrayal-asfull-foreign-aid-cuts-revealed/ (last visited July 7, 2021).

Politico. (2018). "In Balkans, Britain rejoins battle for influence". [online] Available at: http://www.politico.eu/article/balkans-bbc-britain-rejoins-battle-for-influencerussia-soft-power/ (last visited July 7, 2021).

Politico. (2019) "Non-Paper Reforming the European Union accession process". [online] Available at: https://www.politico.eu/wp-content/uploads/2019/11/ Enlargement-nonpaper.pdf (last visited July 7, 2021).

Privredna komora Srbije. (2021). [online] Available at: https://pks.rs/vesti/pocelaprimena-sporazuma-sa-velikom-britanijom-4427 (last visited July 7, 2021).

Pushing on a String. (2020). "An Evaluation of Regional Cooperation in the Western Balkans". Guetersloh: WIIW and Bertelsmann.

Soft Power. (2016). Soft Power. [online] Available at: https://softpower30.com/. (last visited July 7, 2021).

Srbija i Bregzit. (2016). Helsinška povelja, p. 162.

Statista. (2020). "Polish nationals population UK 2020". [online] Available at: https:// www.statista.com/statistics/1061639/polish-population-in-united-kingdom/ (last visited July 7, 2021).

The Economist. (2015). "Softly does it". [online] Available at: http://www.economist. com/britain/2015/07/18/softly-does-it (last visited July 7, 2021).

The Foreign Policy Centre. (2020). "Finding Britain's role in a changing world". [online] Available at: https://fpc.org.uk/programmes/finding-britains-role-in-the-world/ (last visited July 7, 2021).

The Guardian. (2017). "Number of Romanians and Bulgarians in UK rises to 413,000". [online] Available at: https://www.theguardian.com/uk-news/2017/oct/11/ number-of-romanians-and-bulgarians-in-uk-rises-413000 (last visited July 7, 2021).

Times Higher Education. (2021). "World University Rankings". [online] Times Higher Education (THE). Available at: https://www.timeshighereducation.com/worlduniversity-rankings/2021/world-ranking\# (last visited July 7, 2021). 
Visa Application Fees. [2021] Available at: https://visa-fees.homeoffice.gov.uk/y/ serbia/eur/visit/standard-visitor-visa---for-uk-isle-of-man-jersey-and-guernsey/ longer-term-valid-for-up-to-2-years (last visited July 7, 2021).

Way, L.A. and Levitsky, S. (2007). "Linkage, Leverage, and the Post-Communist Divide". In: East European Politics and Societies: and Cultures, 21(1), pp.48-66.

Zeit online. (2021). "Lesen Sie zeit.de mit Werbung oderim PUR-Abo. Siehaben die Wahl". [online] Available at: http://www.zeit.de/politik/ausland/2020-12/brexit-greatbritain-economy-covid-19-european-union-nationalism/komplettansicht\#print (last visited July 7, 2021). 